\title{
LEGAL CHALLENGES OF REDUCTION OF THE TAX BURDEN ON LABOUR IN THE REPUBLIC OF CROATIA
}

\author{
Emina Jerković, PhD, Assistant Professor \\ Josip Juraj Strossmayer University of Osijek, Faculty of Law \\ Stjepana Radića 13, Osijek, Croatia \\ ekonjic@pravos.hr
}

\section{ABSTRACT}

Factor of labour has major role in the functioning of the economy. When it comes to employees, the remuneration they receive for their work, usually called pay or income, is in principle their main source of income and therefore has a great impact on their ability to spend and I or save. The paper analyzes the effect of changes in tax rates in the system of mandatory social contributions and personal income tax on tax burden on labour in Croatia. When it comes to the tax burden on labour, it is about taxation of the gross income of natural persons. The gross income of natural persons in Croatia is taxed with several tax forms: employer and employee mandatory social contributions, personal income tax and surtax to personal income tax. Changes in tax rates and other tax elements (eg personal deduction, tax brackets) are subject to frequent changes in order to achieve certain goals of economic and fiscal policy. EUROSTAT data show that Croatia is in the top five EU countries when it comes to tax burden on labour. Measures of tax policy and numerous tax reforms have tried to correct this fact. The main objective of this paper is to review the effects of such changes on the overall tax burden, the tax burden distribution and progressiveness and the level of tax revenues (fiscal impact).

We consider it important to note that the framework of this paper does not allow a detailed analysis and that we are forced to limit ourselves exclusively to some aspects of the issue at hand.

Keywords: tax burden, personal income tax, mandatory social contributions, surtax to personal income tax 


\section{INTRODUCTION}

The tax burden of the workforce is an important part of financial and tax policy that may significantly influence the level of personal consumption and the employment rate in the country. Successful tax policy is not capable of solving all of the economic disbalances but it can contribute to creating balance and some other specific goals which can be achieved by instruments of tax policy, i.e. social goal of taxation.

„Namely, scientific and expert public views often identify personal income tax as key element in taxation of labour in the Republic of Croatia. Social contributions and surtax to personal income tax which also burden income derived from labour are frequently forgotten. "1

Individual income taxes, payroll taxes, and value-added taxes (VAT) make up a large portion of many countries' tax revenue. In many countries these taxes are progressive, which means that higher-income workers are taxed at higher rates. "The value added tax (VAT), and especially the one where taxation is made on a single-rated system, places the tax burden regressively ${ }^{2}$ in relation to the income of the taxpayer. Since the relative share of income spending falls as income rises, the value added tax, cut at a uniform tax rate, harder affects the poorer than the richer population. "3 However, this does not mean that the average worker is not also burdened by these taxes. It is also important to note that the tax burden on families is often lower than the burden on single, childless workers making the same pretax income. This is a result of not wanting to fulfill only the main goal of taxation, i.e. the fiscal goal, but the social goal of taxation aswell.

The tax burden on labour is broader than personal income taxes and payroll taxes. In many countries individuals also pay a value-added tax (VAT) on their consumption. „Because a VAT diminishes the purchasing power of individual earnings, a more complete picture of the tax burden should include the VAT. Accounting for VAT rates and basis in OECD countries increases the average tax burden on labour by 5 percentage points. “4

1 Šimović, H.; Deskar Škrbić, M., Učinak promjena poreznih stopa na porezno opterécenje rada u Hrvatskoj, EFZG Working paper series, No. 15-13, 2015, p. 4, [http://www.rsp.hr/ojs2/index.php/rsp/ article/view/337/34] Accessed 15.03.2019

2 The biggest criticism of the VAT on which taxation is carried out at one rate is that in relation to income, the tax burden is regressively distributed. The regressive effect of the value added tax does not take into account the principle of vertical equity in the allocation of tax burdens

3 Šimović, J., Socijalni učinci poreza na dodanu vrijednost, Revija za socijalnu politiku, Vol. 5, No. 2, 1998, [http://www.rsp.hr/ojs2/index.php/rsp/article/view/337/341] Accessed 25.03.2019

4 Bunn, D.; Fornwalt, A., A Comparison of the Tax Burden on Labor in the OECD, 2018, Tax Foundation, [https://taxfoundation.org/comparison-tax-burden-labor-oecd-2018/] Accessed 15.03.2019 
As far as employees are concerned, the compensation received for their work, more commonly called wages or payrolls, generally represents their main source of income and therefore has a major impact on their ability to spend and/or save. Whereas gross wages/payrolls include the social contributions payable by the employee, net earnings are calculated after deduction of these contributions and any amounts which are due to government, such as income taxes. ${ }^{5}$

„Labour taxes are considered to be relatively harmful to growth and employment as they depress labour supply and demand by increasing the gap between the cost of labour and employees' take-home pay. Some groups within the population are considered particularly responsive to changes in after-tax wages, e.g. low-income earners and second earners." 6

\section{TAX WEDGE}

It is very ungrateful and complicated to compare different tax systems. There are no two identical tax systems in the world, because of the many factors that shape them. But that does not mean that there are no comparisons when it comes to tax burdens of labour. Tax wedge represents the total tax burden of labour. For comparison between two and more countries tax wedge is calculated on an example of average income. But not all categories of personal income come into consideration - only employment income.

Tax wedge equalls total of personal income tax, surtax to personal income tax and employee's mandatory contributions divided with total expenses of labour (gross salary and employers' mandatory contributions).

There are two methodologies that can be applied- KPMG and OECD methodology. European Commission uses OECD methodology when comparing tax burden of lower paid workers in member states of the EU. OECD methodology considers taxes in broader sense including mandatory social contributions paid to the central government. Also when making the simulations concerning tax wedge it has to be decided whether we are taking into account single workers ${ }^{7}$, families ${ }^{8}$ and

5 Eurostat statistics explained, [https://ec.europa.eu/eurostat/statistics-explained/index.php?title=Wages_ and_labour_costs] Accessed 10.03.2019

6 Tax Reforms in EU Member States 2015, Tax policy challenges for economic growth and fiscal sustainability X/2015, European Commission, Luxembourg: Office for Official Publications of the European Communities, ISBN 978-92-79-51181-3, p. 25

7 OECD defines single worker as an unmarried person, whose presence is definitely larger with population under 40 years of age

8 Tipical family is defined as family with two children between 5 and 12 years of age, but not that exact age but rather 6 or 11 years of age in maximum 
sex of the targeted group. „Also OECD methodology takes into account standard tax deductions when calculating tax burden of tax payers. Many countries in the OECD provide some targeted tax relief for families with children. "9 The Republic of Croatia has also recognized social aspect of taxation in the sense of non-taxable part of income which consists of personal deductions and allowances for children, kept household members, sorts of personal disabilities and pensioners. „While the average tax wedge for single workers in the OECD is $35.9 \%$, the average wedge for families, defined as including a single income earner filing jointly with two children is $26.1 \%$. Poland has the largest disparity between the two tax wedges with a 25.6 percentage-point difference between its $35.6 \%$ wedge for single workers and $10 \%$ wedge for families. The lowest family tax wedge is in New Zealand at $6.4 \%$, which is just slightly lower than Chile, which has a $7 \%$ wedge for both single and family taxpayers. " ${ }^{10}$

According to the European Commission's assessment, the tax wedge in Croatia in 2014 amounted to $36 \%$ for single workers (without children) who earn 67\% of average income. Most of burden refers to employee contributions - $17.1 \%$, while the share of personal income tax amounts to $7.6 \%$. On the other hand, in Croatia, taxes are presented according to the cash principle - tax data only contains data on collected, but not uncollected taxes. Therefore, for a more complete comparison of the tax burden with that of other members, Croatian data should be increased for the amount of uncollected taxes. Accurate, up-to-date and statistically verified data on total unpaid taxes and contributions at the general government level are not available in the Republic of Croatia. However, it is clear from the information published by the Tax Administration that the debt amounts to tens of billions of $\mathrm{HRK}^{11}$.

„There is a negative relationship between the tax wedge and emloyment. “12 „Because of this, countries should explore ways to make their taxation of labour less burdensome to improve the efficiency of their labor markets. "13 The effectiveness of reductions in labour tax in reducing unemployment depends on the interaction of the demand and the supply side of the labour market, which is determined by the behavioural responses of businesses and workers, measured in terms of elastici-

\footnotetext{
9 Bunn; Fornwalt, op.cit., note 2

10 OECD Publishing, Taxing Wages 2018, [https://read.oecd-ilibrary.org/taxation/taxing-wages-2018_ tax_wages-2018-en\#page7] Accessed 15.03.2019

11 Bejaković, P., Oporezivanje rada: Može li flat tax riješiti hrvatske probleme?, [https://prviplan.hr/analizei-komentari/oporezivanje-rada-moze-li-flat-tax-rijesiti-hrvatske-probleme/] Accessed 15.03.2019

12 Hodge, S. A.; Hickman, B., The Importance of the Tax Wedge on Labor in Evaluating Tax Systems, [https:// files.taxfoundation.org/20180913095728/Global-Primer_tax_wedge.pdf] Accessed 15.03.2019

13 Bunn; Fornwalt, op.cit., note 2
} 
ties. The greater the response to tax changes on the part of employers or employees, the higher the elasticity of labour demand or supply, respectively. ${ }^{14}$

\section{TAX BURDEN OF LABOUR IN THE REPUBLIC OF CROATIA}

Tax burden of labour refers to taxation of gross personal income of natural persons. Gross personal income of natural persons in the Republic of Croatia is taxed via few fiscal forms:

1. mandatory social contributions

a) contributions that burden the employer, i.e. health insurance contribution (16.5\%)

b) contributions that burden the emloyee, i.e. pension insurance contributions $(15 \%+5 \%)$

2. personal income tax

3. surtax to personal income tax.

All of the above mentioned contributions and taxes are madatory. The only difference is the technic of accounting when it comes to independent services where the entire amount of social contributions is beared by the person which provides the independent service.

"Croatia is not a leader in the amount of the tax burden on labour, but it is among the countries with a higher tax wedge. The problem in Croatia is not the income tax, which is relatively low compared to other countries, but in the first place the problem are contributions, especially those paid by employees, where Croatia has one of the heaviest burdens in the word." 15

Citizens are not sufficiently aware which taxes they pay and how much. Part of the reason for this is the system of taxation of wages in which the employers are obliged on behalf of the employees to calculate contributions and taxes, and pay them into the government budget account. Only the net wage is paid into the employee's account. Of course, the employee, when receiving the wage, must be given a wage slip by the employer clearly showing the amount of gross wage and individual taxes and contributions. ${ }^{16}$

14 Tax Reforms in EU Member States 2015, op. cit., note 4, p. 33

15 Krtalić, S.; Žgomba, B., Analysis of the tax wedge in the Republic of Croatia, The EU economic environment post-crisis: Policies, Institutions and Mechanisms, Juraj Dobrila University of Pula, Pula, 2016, pp. $75-76$

16 Urban, I., Porezno opterécenje rada u Hrvatskoj, Newsletter, povremeno glasilo Instituta za javne financije, No. 47, 2009, p. 2 


\subsection{Social contributions}

General government ${ }^{17}$ includes not only all fiscal levels (state, regional and local self-government units), but also various non budget funds as a special form of state units. Tipical examle of these sort of funds are social insurance funds which can be formed as a special subsector within every level of public governance, but are often found on the central governence. ${ }^{18}$

According to the above mentioned, mandatory social contributions that are payed to general government or to be more specific to one of the non budget funds (i.e. social security funds) can be deemed as taxes by the OECD methodology. The main similarity to taxes is their obligatory character, i.e. they are both fiscal revenue of the state (or the regional and local-self-government units). But they also differ from taxes in a way of equivalence and benefit that obliged persons receive from payment of social insurance in a form of pensions and health insurance. In most countries the benefit depends on payments of adequate contribution, although the amount of the benefit is not necessarily connected to the amount of the contribution ${ }^{19}$ which implies that the social insurance contributions are payments without direct equivalence. ${ }^{20}$

It should be noted that their obligatory character is not enough to consider them sort of taxes, but it is necessary that they are paid to general government which brings us to one big dilemma- should the pension insurance contributions deriving from the second pillar be included in the forming of tax wedge. If so the results would represent the position of the Republic of Croatia in a unfavorable light than it really is. One of the argument for their inclusion besides their obligatory character is relatively high level of state supervision of non budget funds they belong to. But their exclusion, although methodologically consistent, would result in better light of the Republic of Croatia in relation to actual state.

Also one of the problems is the fact that immediately after the pension insurance reform in 2002 there were workers over the age of 50 that were not obliged to pay pension insurance contributions in two divided pillars but remained in just one pillar ( $20 \%$ of the gross income) and the workers between ages 40 and 50 had to make the choice whether to remain in one pillar or to pay pension insurance con-

17 IMF Government Finance Statistics manual 2001, Washington DC:IMF, 2001, pp.12-14

18 Blažić, H.; Trošelj, I., Međunarodna usporedba poreznog opteréénja radne snage: Utjecaj nove metodologije na položaj Hrvatske, Financije i menadžment u globalnoj ekonomiji, Pula: Sveučilište Jurja Dobrile u Puli, Odjel za ekonomiju i turizam, 2012, p. 30, [https://bib.irb.hr/datoteka/589765.Blazic_Troselj_-_Copy.pdf] Accessed 15.03.2019

19 OECD Revenue Statistics 1965-2010, OECD, Paris, 2011, p. 303

20 OECD Publishing, Taxing Wages 2008-2009, OECD, Paris, 2010, p. 27 
tributions in two pillars. „Only $30 \%$ of those workers decided to join the second pillar." ${ }^{21}$

Social contributions are at one hand very simple, but at he other hand very rigid instrument of labour taxation. „Rates of mandatory contributions are directly applied to the amount of gross income for all obliged persons (which equate with tax payers) without any deductions, allowances or differentiated rates. "22

There were not may changes since 2002 pension reform up till now when it comes to mandatory pension insurance contributions. There are two mandatory pillars of pension insurance contributions: First pillar deals with generational solidarity system $-15 \%$ of the gross income and the second pillar mandatory individual pension insurance- $5 \%$ of the gross income. There is also a third pillar-voluntary pension insurance. The second and the third pillar represent individual capitalised savings by insured person.

There were some changes concerning health insurance contributions. The changes concern lowering rate of the health insurance contribution from $15 \%$ to $13 \%$ in May of 2012 and recall of that change in April of 2014. But the biggest change occured in 2019. Three of the mandatory social contributions payed by employer (health insurance contribution - 15\%, contribution concerning work related injuries $-0.5 \%$ and contribution with assisting employment-1.7\%) were incorporated in one health insurance and health insurance in case of workplace injury and profession-related illness contribution - $16.5 \%$ in $2019 .{ }^{23}$

„It should be noted that mandatory social contributions are usually proportional, i.e. they do not change with the growth of the personal income. But in recent times some countries have displayed changes that make these sort of social contributions progressive but not indefinitely. ${ }^{24}$

When it comes to the Republic of Croatia, it does not matter whether the mandatory pension contributions in the second pillar are included in the analasys, tax burden of labour is very high. „According to the data for average pay, higher burden than the Republic of Croatia have only Austria, Germany, Netherlands and Greece, but to us more comparable Poland, Hungary, Slovenia (whose burden is the largest-22\%). Turkey has the same burden as Croatia. Slovakia and Chech

\footnotetext{
21 Zuber, M., Mogućnosti poboljšanja socioekonomskih i fiskalnih učinaka sustava obveznog mirovinskog osiguranja u Hrvatskoj, doktorska disertacija, Sveučilište u Rijeci, Ekonomski fakultet, rijeka, 2011, p. 130

22 Šimović; Deskar Škrbić, op. cit., note 1, p. 5

23 Law on contributions, Official Gazzette No. 106/2018

24 Blažić; Trošelj, op.cit., note 15, p. 13
} 
Republic have somewhat lower burden (13.4\% and $11 \%)$. The view of the burden depends on the fact of who are we looking at- old memeber states or new member states, or all together. ${ }^{\text {} 25}$

„Also, the survey shows that $5 \%$ rate of the second pillar of mandatory pension contribution is very high compared to other OECD countries. Only Chile and Switzerlad have higher rate. " ${ }^{26}$

\subsection{Personal income tax}

When it comes to comparison of personal income tax, one should be very careful because of the definition of tax basis varies from country to country. Some countries have all sorts of personal deductions, allowances and incentives that make it much harder to see the real state of things. ${ }^{27}$ As far as the Law on Personal Income Tax has been concerned, it has had seven amendments to the law since 1993 to improve and upgrade the tax system of the Republic of Croatia, which resulted in the adoption of the Second Law on Personal Income Tax. This second law also experienced several changes in 2004, 2008, 2010, 2011, 2012. The last change took place in 2019, which will continue to be discussed. When it comes to taxation of income from employment for the purpose of achieving the principle of equity, the most experimented with were the number of tax rates and tax brackets ranging from two $(20 \%$ and $35 \%)$ to three $(15 \%, 25 \%, 35 \%)$, four $(15 \%, 25 \%$, $35 \%, 45 \%)$, than three tax rates and tax brackets $(12 \%, 25 \%, 40 \%)$ and last changes stopped at two tax rates $(24 \%$ and $36 \%)$ and non-taxable part of income or basic personal allowance (HRK 1,000, HRK 1,250.00, HRK 1,500.00, HRK 1,600.00, HRK 1,800.00, HRK 2,200.00, HRK 2.600,00, HRK 3.800,00).

The Law on Personal Income $\operatorname{Tax}^{28}$ was adopted in 1993. With the beginning of its application since 1994 it replaced the existing law that has been in effect since 1991. Under the new law, the form of personal income tax has been replaced by a synthetic personal income tax with the application based on the principle of world income.

Two tax rates have been introduced - a minimum of $25 \%$ and a maximum of $35 \%$. For such established rates of personal income tax, as well as the range between them, it can be said that „the minimum rate was among the highest, and the highest rate among the lowest compared to the then tax systems of most coun-

\footnotetext{
25 Cf. ibid., p. 14

26 Cf. ibid., p. 15

27 Bejaković, op.cit., note 9

28 Official Gazette, No. 109/1993
} 
tries (not only European), and the range between these two rates (10 percentage points) was one of the smallest ranges between the input and output rates of that tax during those years. “29 „At that time the range between tax rates in the European countries was, for example, $40 \%$ in Austria, Luxembourg and Greece, $41 \%$ in Italy, 25 in Portugal, 30 in Belgium, 32 in Finland, 34 in Germany and 23\% in the Netherlands. ${ }^{\text {30 }}$

One of the goals of tax policy is to achieve fairness in taxation. When it comes to personal income tax, especially in terms of employment income and independent services income, this fairness is generally tied to income taxation by applying a progressive tax rate, whereby the optimum situation would assume the existence of larger number of rates with the lenient drop between the rates. The taxpayer in terms of the amount of earned income, or more precisely with respect to the tax basis, enters a certain tax bracket where his income is taxed at a certain tax rate. This automatically leads to a more even tax burden distribution, i.e. lower income taxpayers will enter lower tax brackets and pay taxes at lower tax rates, and taxpayers who generate higher income would enter higher tax brackets and pay tax at higher tax rates. The authors of the Law on Personal Income Tax of 1993 thought of this, but the realization of that idea in practice did not occur. It is difficult to talk about fairness in taxation if only two rates are applied in the taxation of personal income tax, with the minimum rate being set extremely high to $25 \%$, the maximum relatively low to $35 \%$. In this way, the Republic of Croatia differed greatly from the modern countries to which it looked up to and entered into a group of few countries that used only two tax rates when it comes to personal income taxation. A small number of tax rates causes a sudden increase in the tax burden at the transition from one tax bracket to another, which is particularly aggravating circumstance for taxpayers that generate employment income and independent services income.

During 1994, or within the year of application of the Law on Personal Income Tax, major amendments to the Law ${ }^{31}$ were made. Out of 121 articles, 58 were amended, while 6 were deleted. ${ }^{32}$ During 1996 there was another amendment to the Law on Personal Income $\operatorname{Tax}^{33}$, most important of which was that the minimum tax rate has been reduced from $25 \%$ to $20 \%$. However, only two rates were still in use.

\footnotetext{
29 Jelčić, B.; Bejaković, P., Razvoj i perspektive oporezivanja u Hrvatskoj, HAZU, Zagreb, 2012, p. 164

30 Jelčić, B., Je li u nas porezni teret ravnomjerno rasporeden, Ekonomija/Economics No. 3, Zagreb, 1998,p. 328-333

31 Official Gazette, No. 95/1994

32 Jelčić; Bejaković, op.cit., note 26, p. 170

33 Official Gazette, No. 106/1996
} 
After three more amendments to the 1993 Law on Personal Income Tax, there were more pronounced demands and changes in the taxation of income (and profit as well), and in 2000 a new Law on Personal Income $\operatorname{Tax}^{34}$ The new Law on Personal Income Tax entered into force on 1 January 2001 and differed from the previous one not only in the material but also in the formal sense.

The new law has increased the number of tax rates and tax brackets. Initially, there were three rates, $15 \%, 25 \%$ and $35 \%$, and from the beginning of 2003 , a rate of $45 \%$ was introduced to more evenly distribute the tax burden. This is how the range between minimum and maximum tax rates increased by 20 percentage points.

This means, in essence, that after the mandatory pension contributions and the basic personal allowance at the monthly level were deducted from the gross salary, personal income was taxed from 2001 to 2003 as follows:

Table 1: Tax brackets and tax rates from 2001 to 2003

\begin{tabular}{|c|c|}
\hline Tax rate & $\begin{array}{c}\text { Monthly basis } \\
\text { (HRK) }\end{array}$ \\
\hline $15 \%$ & Up to $2.500,00$ \\
\hline $25 \%$ & $2.500,01$ to $5.625,00$ \\
\hline $35 \%$ & Over $5.625,01$ \\
\hline
\end{tabular}

Since 2003, personal income has been taxed using 4 tax rates and 4 tax brackets. It is clear that the basic personal allowance played in an exceptionally large role, which in 2001 amounted to $1250 \mathrm{HRK}$, and since 2003 it has been increased to 1500 HRK.

Table 2: Tax brackets and tax rates from 2003 to 2005

\begin{tabular}{|c|c|}
\hline Tax rate & $\begin{array}{c}\text { Monthly basis } \\
\text { (HRK) }\end{array}$ \\
\hline $15 \%$ & Up to $3.000,00$ \\
\hline $25 \%$ & $3.000,01$ to $6.750,00$ \\
\hline $35 \%$ & $6.750,01$ to $21.000,00$ \\
\hline $45 \%$ & Over $21.000,01$ \\
\hline
\end{tabular}

Since January 1, 2005, the Third Law on Personal Income Tax ${ }^{35}$ has been applied, the essence of which has not changed much in the light of the previous law. The legislator's aim was to further simplify the previous regulation. Of the most interesting changes, one should emphasize the increase of the basic personal tax

\footnotetext{
34 Official Gazette, No. 127/2000, 150/2002

35 Official Gazette, No. 177/04
} 
allowance for the taxpayers to $1600 \mathrm{HRK}$ (up to 3000 for pensioners), changes related to other allowances for dependent members of household -0.50 of the basic personal allowance for spouses or other dependent family members. Also the total amount of deduction for insurance, health care and housing needs was reduced. It is important to emphasize that the new law has established new brackets for the application of tax rates on the taxation of employment income and independent services income.

Table 3: Tax brackets and tax rates from 2005 to 2008

\begin{tabular}{|c|c|}
\hline Tax rate & $\begin{array}{c}\text { Monthly basis } \\
\text { (HRK) }\end{array}$ \\
\hline $15 \%$ & Up to $3.200,00$ \\
\hline $25 \%$ & $3.200,01$ to $8.000,00$ \\
\hline $35 \%$ & $8.000,01$ to $22.400,00$ \\
\hline $45 \%$ & Over $22.400,01$ \\
\hline
\end{tabular}

„During this period, wealthier citizens paid the state approximately $2 / 3$ of the total of personal income tax, while their relative tax burden has risen. "36 In 2008, there is a new increase in the basic personal allowance that came into force from 1 July 2008 and for which the basic personal deduction for the taxpayer is 1800 HRK, and for pensioners with a maximum of 3200 HRK. Thus, there is a new relationship within the tax brackets:

Table 4: Tax brackets and tax rates from 2008 to 2010

\begin{tabular}{|c|c|}
\hline Tax rate & $\begin{array}{c}\text { Monthly basis } \\
\text { (HRK) }\end{array}$ \\
\hline $15 \%$ & Up to $3.600,00$ \\
\hline $25 \%$ & $3.600,01$ to $9.000,00$ \\
\hline $35 \%$ & $9.000,01$ to $25.200,00$ \\
\hline $45 \%$ & Over $25.200,01$ \\
\hline
\end{tabular}

The above mentioned provisions were one of the causes for the new Law on Personal Income Tax that followed in 2010. ${ }^{37}$ Tax rates were changed yet again for taxation of certain forms of income, and some of the tax reliefs (healthcare, housing, insurance premiums, investment maintenance) were abolished.

\footnotetext{
36 Kesner-Škreb, M., Što s porezima u Hrvatskoj? Porezno opterećenje, oporezivanje dohotka, dobiti i imovine, Newsletter Instituta za javne financije, No. 32, p. 4

37 Official Gazette, No. 80/10
} 
Table 5: Tax brackets and tax rates from 2010 to 2013

\begin{tabular}{|c|c|}
\hline Tax rate & $\begin{array}{c}\text { Monthly basis } \\
\text { (HRK) }\end{array}$ \\
\hline $12 \%$ & Up to $3.600,00$ \\
\hline $25 \%$ & $3.600,01$ to $10.800,00$ \\
\hline $40 \%$ & Over $10.800,00$ \\
\hline
\end{tabular}

The application of new tax rates has had an impact on the reduction of tax burden, however, when it comes to taxpayers with the lowest payrolls, the problem lies in the fact that these taxpayers (using the basic personal allowance increased by the other deductions) barely, if at all, reach the tax basis on which tax rates are applied to. This actually means that in the Republic of Croatia, taxpayers who earn income most often from their employment, earn income that is significantly lower than the amount for which they could reduce the tax basis of personal income tax. „A large number of taxpayers of personal income tax generate income that is so low that they will not pay personal income tax, but the fact remains that they lack funds to meet basic living needs whose height is indirectly (by determining the personal allowances and deductions) established by the Law on Personal Income Tax." 38

The income tax base on the taxation of income tax on employment and independent services is divided into three tax categories. In taxation, 3 tax rates $(12 \%$, $25 \%, 40 \%$ ) are used from 2013 to 2017.

This means, in essence, that after the gross salary is deducted from the compulsory contributions and the basic personal allowance of taxable income on a monthly basis is taxed as follows:

Table 6: Tax brackets and tax rates from 2013 to 2017

\begin{tabular}{|c|c|}
\hline Tax rate & $\begin{array}{c}\text { Monthly basis } \\
\text { (HRK) }\end{array}$ \\
\hline $12 \%$ & Up to $2.200,00$ \\
\hline $25 \%$ & $2.200,01$ to $8.800,00$ \\
\hline $40 \%$ & Over $8.800,01$ \\
\hline
\end{tabular}

What is exceptionally interesting is that it was the first time it occurred that when determining the lowest tax bracket and thus applying the lowest tax rate, the legislator did not use a double basic personal allowance but the personal income tax is paid at the rate of $12 \%$ of the salary ranged from the tax base to the height a single amount of the basic personal allowance. Hence, entering a higher tax bracket and

38 Jelčić, B., Oporezivanje uskladiti s našim potrebama i mogućnostima, Ekonomija/Economics, Vol. 13, No. 1, Zagreb, 2006., p. 97 
applying a tax rate of $25 \%$ is much "faster", which greatly increases the tax burden on taxpayers. The fact is that tax rates have been reduced, i.e. $12 \%, 25 \%$ and $40 \%$, instead of $15 \%, 25 \%, 35 \%$ and $45 \%$, and the tax burden has been reduced, especially by abolishing the 4th highest tax rate, but the legislator has made the second step precisely when establishing a new tax system of tax brackets. Surprising is the fact that this problem was not mentioned or even questioned and has been accepted without any delay.

Till the beginning of 2017, personal income was taxed at rates 12, 25 and $40 \%$, and there were also a range of tax deductions and allowances. In addition to the fact that the highest $40 \%$ rate was unproductive and punitive, the additional problem was that it applied to relatively low income. Also, the monthly basis was determined in correlation to basic personal allowance and thus the tax brackets were formed. To improve and simplify the tax system, Croatia has introduced two tax categories in 2017: the $24 \%$ rate is applied to the tax basis of up to HRK 17,500 and the rate is $36 \%$ above that amount (tax rate is applied to the difference between the category of income and monthly basis). The basic personal allowance in Croatia amounted to HRK 2,600 per month prior to 2017, and now amounts to HRK 3,800 per month. Tax basis is now calculated according to net minimum wage in the Republic of Croatia and has no connection to basic personal allowance.

Table 7: Tax brackets and tax rates from 2017 to 2019

\begin{tabular}{|c|c|}
\hline Tax rate & $\begin{array}{c}\text { Monthly basis } \\
\text { (HRK) }\end{array}$ \\
\hline $24 \%$ & Up to $17.500,00$ \\
\hline $36 \%$ & Over $17.500,01$ \\
\hline
\end{tabular}

In 2019, monthly basis has been changed yet again. ${ }^{39}$

Table 8: Tax brackets and tax rates from 2019

\begin{tabular}{|c|c|}
\hline Tax rate & $\begin{array}{c}\text { Monthly basis } \\
\text { (HRK) }\end{array}$ \\
\hline $24 \%$ & Up to $30.000,00$ \\
\hline $36 \%$ & Over $30.000,01$ \\
\hline
\end{tabular}

A progressive tax rate is not crucial when considering the distribution effect because a more even or "fairer" tax burden distribution can be achieved with a lower number of tax rates and brackets, but with personal deductions and allowances. So in the end, tax on labour results in lower salaries for workers (but we should

39 Law on personal income tax, Official Gazette, No. 115/2016, 106/2018 
not forget the effect of other taxes which also reduce employees' standard of living, such as VAT and excise taxes). "What if employees do not want to accept lower wages? They have several "escape routes": (a) to the unofficial economy and tax evasion - to accept payment of a small proportion of or the entire salary "on the black", (b) to inactivity - withdrawal from the labour force and the search for social benefits from the government, (c) abroad - this may relate to young people and educated and qualified workers." ${ }^{0}$

\subsection{Surtax to personal income tax}

It should not be forgotten to mention, especially when it comes to the financing of local self-government units, the connection of personal income tax with surtax to personal income tax. The Law on Financing Local and Regional Self-Government Units $^{41}$ and Law on Local Taxes ${ }^{42}$ provide municipalities and cities with the possibility of introducing this sort of tax revenue. A taxpayer of personal income tax is obliged to pay surtax to personal income tax if he/she has a permanent or temporary residence in the municipality or city that has prescribed the payment of the surtax. The basis of the surtax is calculated income tax. When it comes to the tax rate, municipalities and cities may set the following tax rates:

- the municipality can prescribe a rate of up to $10 \%$

- a city below 30,000 inhabitants can prescribe a rate of up to $12 \%$

- a city over 30,000 inhabitants can prescribe a rate of up to $15 \%$

- The city of Zagreb can prescribe a rate of up to $18 \%$.

In practice, this means that the tax burden will vary depending on the taxpayer's domicile. For example, the city of Osijek prescribes the rate of income tax rate of $13 \%$, while the City of Zagreb prescribes a rate of $18 \%$. Another example is $\mathrm{Za}$ dar, a city that until 2012 did not have surtax to personal income tax. This means that taxpayers with equal income will pay different amounts of tax or non at all, thereby automatically failing to meet the criteria of fairness and also affect the tax burden statistics.

\footnotetext{
40 Urban, op. cit., note 13 , p. 10

41 Law on financing regional and local self-government units, Official Gazette, No. 127/2017

42 Law on local taxes, Official Gazette, No. 115/2016, 101/2017
} 


\section{MEASURES OF SOLVING LABOUR TAX WEDGE PROBLEMS IN THE EU}

The overall tax burden in the EU is above the OECD average and is skewed towards labour. For euro area Member States, the tax burden on labour, as measured by the tax wedge is among the highest in the world. Taxes on (employed) labour income are the most important source of revenue, contributing nearly half of all revenues, followed by consumption taxes at roughly one third and capital taxes at around one fifth of all tax revenues in the euro area." In some Member States, labour taxation is also designed in such a way that it discourages specific groups (e.g. low income earners) from taking up work, which may raise fairness issues. " 43

„Taxation can significantly affect employment trends in the economy. Excessive taxation can disturb the proper functioning of labour market by distorting incentives for work. Emphasis of tax policy should increasingly be put on finding those elements of the tax system which cause biggest distortions and bring them to the minimum. It is generally recommended to reduce the total tax burden in the economy, disperse the tax burden from the employers and workers to other tax forms with broader tax base (such as consumption) and increase flexibility on the labour market. “44

Following its commitment to reduce the tax burden on labour, the Eurogroup ${ }^{45}$ agreed on a benchmark and on common principles of which one refers to financing issues. „Although, the general discussion how to boost (inclusive) growth and employment has highlighted the importance of reducing labour taxation, some Member States face the question how to finance a labour tax cut, given their consolidation needs and/or sustainability challenge. The answer very much depends on country-specific circumstances. "46

In 2014, the Eurogroup agreed on common principles which should guide Member States when reducing the tax wedge on labour. The conclusion is that reductions of the tax burden on labour need to be duly compensated, while taking into account the country specific fiscal margin for manoeuvre.

43 European Commission, Financing labour tax wedge cuts, Brussels, 2017, p. 3

44 Deskar Škrbć, M; Drezgić, S.; Šimović, H, Tax policy and labour market in Croatia: effects of tax wedge on employment, Journal Economic Research-Ekonomska Istraživanja, Vol. 31, 2018, [https://www. tandfonline.com/doi/full/10.1080/1331677X.2018.1456359?scroll=top\&needAccess=true] Accessed 03.04.2019

45 The Eurogroup is the recognised collective term for informal meetings of the finance ministers of the eurozone - those member states of the European Union (EU) which have adopted the euro as their official currency. The group has 19 members. It exercises political control over the currency and related aspects of the EU's monetary union such as the Stability and Growth Pact

46 Cf. ibid., p. 2 
After the Eurogroup agreement in September 2015, several Member States have undertaken reforms to address the high tax wedge on labour. More recently, however, reform efforts have decreased and Member States have identified the financing of labour tax reductions as a key challenge in this context. „In line with the common principles adopted in September 2014, financing options include:

1. An uncompensated labour tax reduction

2. A revenue-neutral tax shift

3. An offsetting expenditure cut. ${ }^{\text {“47 }}$

\subsection{An uncompensated labour tax reduction}

Although we can compare the main challenges across Member States, countryspecific circumstances need to be taken into account, also in full respect of the existing EU economic surveillance framework, in particular the Stability and Growth Pact.

According to the report of European Commission, given the overall limited fiscal space, only few Member States appear to have the fiscal space to reduce the tax burden on labour without the need to offset revenue losses. In 2016, only Germany, Latvia, Lithuania and Austria in the euro area (tax wedge for low-income earners) had enough fiscal margin for manoeuvre to consider an uncompensated labour tax cut. Some Member States face a need to decrease relatively high taxes on labour (overall or for low-income groups) but are still facing a fiscal sustainability challenge.

„Given that public finances are strained in many Member States, and in order to avoid putting fiscal sustainability at risk, a labour tax reduction would have to be financed by reducing public expenditure or by increasing alternative revenues. " ${ }^{48}$

\subsection{A revenue-neutral tax shift}

„A revenue-neutral tax shift towards consumption taxes - or to other taxes less detrimental to growth - could be explored in several Member States. Labour taxes are considered to have a particularly negative effect on growth and employment, whilst certain other taxes are generally considered less distortive. "49 A labour tax cut can be financed by increasing other taxes to offset the revenue loss, in particular for Member States that face a need to decrease relatively high taxes on

Cf. ibid., p. 4

48 Tax Reforms in EU Member States 2015, op.cit., note 4, p. 28

49 Ibid. 
labour, while having relatively low taxes in some areas considered less detrimental to growth. In this respect, recurrent taxes on immovable property ${ }^{50}$ were found to be least harmful for economic growth, followed by consumption taxes, personal income taxes, environmental taxes and capital taxes. Inheritance taxes may also have only a small effecton economic behaviour. ${ }^{51}$ In particular, a tax shift from labour to consumption ${ }^{52}$, at an unchanged overall revenue level, can be relevant. ${ }^{53}$ "If the reform takes the form of a revenue-neutral tax shift, there is no financing issue, since the reformed system is expected to raise the same amount of revenue as the existing system. Increased attention for inequality, fairness and redistribution might make tax shifts towards capital taxation (e.g. taxation of capital gains, inheritance tax) more attractive." 54

When considering potential increases in consumption taxes, it is important to examine which specific types of tax can potentially be increased (e.g. VAT or excise duties). „Also, broadening the tax base may be preferred to raising the standard tax rate as a way of increasing revenue, as it minimises distortions. Improving tax compliance can also be a meaningful way of increasing revenue for several Member States." 55

„If growth-friendly taxes are currently relatively low, a Member State could increase these taxes as a way of increasing public revenue. This additional revenue may then be used to help improve the sustainability of public finances or to finance a reduction in labour taxes." 56

50 In some countries, for example, labour taxes are collected nationally whilst all or some recurrent property taxes are set and paid at local level. The revenue generated from recurrent property taxes may also serve different purposes in different countries, e.g. it may simply contribute to the government's general budget, or it may be specifically allocated to financing local services

51 Tax Reforms in EU Member States 2015, loc.cit

52 Austria substantially reduced labour taxation in 2016. The reform package included an increase in the number of brackets in the personal income tax system, an increase in the amounts of several allowances and tax credits, and an increased reimbursement of social security contributions for low-income earners. Measures to finance the tax relief include among others measures to improve tax compliance, spending cuts in administration, and an increase of several other taxes (such as the reduced VAT rate for certain goods or the withholding tax on capital gains). Increased consumption tax revenue from an increase in the purchasing power of consumers is expected to finance $17 \%$ of the reform

53 A rise in taxes, and in particular a rise in consumption taxes, could increase prices, leading to higher inflation in the short run. Depending on how wages react to higher prices, which in turn is also influenced by indexation of benefits, this may lead to wage increases that, at least partly, counteract the reduction in labour costs resulting from the tax shift (referred to as the 'second round effect'). If wages do not react quickly, a shift from labour to consumption taxes could have the same effect as a currency devaluation

54 European Commission, Financing labour tax wedge cuts, op.cit., note 39, p. 6-7

55 Tax Reforms in EU Member States 2015, op.cit., note 4, p. 29

56 Cf. ibid., p. 28 


\subsection{An offsetting expenditure cut}

In September 2016, the Eurogroup called on euro area Member States to actively use spending reviews and approved a set of common principles for improving expenditure allocation through their use ${ }^{57}$. Member States also face calls from different directions to promote the quality of public spending in order to create favourable conditions to support investment.

In this context, a labour tax cut can be financed in a budget-neutral manner by cutting or by better and more efficient use of public expenditure. Reviews and reforms of priorities in public expenditure could contribute to a more overall growth-friendly composition of the budget. This option is particularly relevant for countries with both high labour taxation and important fiscal sustainability issues.

One way in which Member States can cut expenditures is by limiting the use or reducing the generosity of tax expenditures. Tax expenditures are generally reductions in government revenue through preferential tax treatment of specific groups of tax payers or specific economic activities. An important role for the final fiscal impact is the amount of tax returns. Tax return is obligatory only for taxpayers who change their employer in the fiscal year and for tax payers of independent services income. Other cases of tax filing apply to the possibility of achieving certain, mostly non-standard, tax reliefs. When it comes to the Republic of Croatia in 2010 some of the tax reliefs (healthcare, housing, insurance premiums, investment maintenance) were abolished which subsequently significantly reduced the amount of tax returns on the basis of these reliefs.

While tax expenditures may be motivated by relevant economic or social goals, they are not necessarily the most cost efficient instrument and may in some cases lead to severe economic impacts and distortions. „Possible tax expenditure cuts could also concern those which are too expensive to maintain, with potentially large revenue losses, with large administrative and compliance costs or which can be replaced by more efficient measures. " ${ }^{8} 8$

„Belgium, the Czech Republic, France, Italy, Latvia, Hungary, Austria, Portugal and Romania and, to a lesser extent, Germany, Estonia, Croatia Lithuania, the Netherlands, Finland and Sweden, appear to have both a potential need to reduce a relatively high tax burden on labour (either overall or for specific groups) and

\footnotetext{
57 [http://www.consilium.europa.eu/en/press/press-releases/2016/09/09-eurogroup-statement/] Accessed 14.03.2019

58 European Commission, Financing labour tax wedge cuts, op.cit., note 39, p. 8-9
} 
potential scope to increase the least distortive taxes. These Member States could, therefore, consider shifting the tax burden away from labour." ${ }^{\text {"59 }}$

\section{CONCLUSION}

Factor of labour has a major role in the functionig of the economy of every country in the world. From the point of view of the employer labour represents expenses, which besides salaries paid to employees, includes expenses calculated on the salaries, mainly mandatory social contributions. ${ }^{60}$

There are many analyses and empirical researches in the Republic of Croatia that take interest in tax burden of labour, having personal income tax especially in focus. But not many of them see the impact the mandatory social contributions have on the tax wedge. There are many tax changes and even tax reforms regarding personal income tax, and just a few changes concerning mandatory social contributions. Taking into account results of these researches ${ }^{61}$, that show how more fair redistribution of tax burden can be achieved with less tax rates and consequently less tax brackets, in recent years there has been a sort of tax reform that reduced number of tax rates from four to three at first and then in 2018 from three to two tax rates- $24 \%$ and $36 \%$.

The simple fact is that high tax burdens discourage employers to hire new workers, existing employees are paid the minimum salary and consequently employers and employees pay less mandatory contributions and consequently encourage the shadow economy, most often in the form of salary disbursement in informal way which leads to tax evasion, boost incentives for reduction of employment in recessions and stimulate employment in informal sector of the economy.

Higher employers' mandatory social contributions automatically mean higher expenses for the employers themselves. "The defeating fact is that employers shift the burden of mandatory social contributions to the employees, while employees are not able to shift the burden to another market participant and have to, in the end, bear the total burden of not just taxes but mandatory social contributions

59 Tax Reforms in EU Member States 2015, op.cit., note 4, p. 31

60 Although we consider labor as a key factor when it comes to competitiveness of companies, there are other factors that should be taken into account, e.g. capital expenses (interest on loans and dividends on equity) and non-price elements (entrepreneurship, skills and labor productivity, inovation and position of brand and product marketing)

${ }_{61}$ See Urban, I., Jedna stopa unutar poreza na dohodak: utjecaj na raspodjelu poreznog tereta, Povremeno glasilo Instituta za javne financije, Newsletter No. 24, 2006 
aswell. Consequently, higher employers' contributions result in lower net salaries for employees." 62

Much talked about pressure release of employers when it comes to mandatory social contribution has come to order in 2019. Three of the mandatory social contributions payed by employer (health insurance contribution- $15 \%$, contribution concerning work related injuries- $0.5 \%$ and contribution with assisting employment-1.7\%) were incorporated in one health insurance contribution- $16.5 \%$.

Governments with higher taxes generally present to the public that they provide more services as an explanation, and while that is often true, the cost of these services can be more than half of an average worker's salary, and for most, at least a third of their salary. ${ }^{63}$

A high tax burden on labour is a clear impediment to an efficient and smooth functioning of labour markets and runs counter to the goal of boosting economic activity and increasing employment. Reducing the tax burden on labour has the potential to support consumption, stimulate labour supply and create work incentives for low-income earners, as well as to improve firms' and employers' profitability, progress, productivity and cost-competitiveness. It should therefore increase demand, growth and support job creation on the labour market, what is extremly important for countries in transition like the Republic of Croatia. Tax systems and especially social contribution systems should be formed in such a way that they create as little obstacles as possible when it comes to employment and enterpreneurship.

\section{REFERENCES}

\section{BOOKS AND ARTICLES}

1. Jelčić, B., Je li u nas porezni teret ravnomjerno raspoređen, Ekonomija/Economics No. 3, Zagreb, 1998

2. Jelčić, B., Oporezivanje uskladiti s našim potrebama i mogućnostima, Ekonomija/Economics, Vol. 13, No. 1, Zagreb, 2006

3. Jelčić, B.; Bejaković, P., Razvoj i perspektive oporezivanja u Hrvatskoj, HAZU, Zagreb, 2012

4. European Commission, Financing labour tax wedge cuts, Brussels, 2017

5. IMF Government Finance Statistics manual 2001, Washington DC:IMF, 2001

6. Kesner-Škreb, M., Što s porezima u Hrvatskoj? Porezno opteré́enje, oporezivanje dohotka, dobiti $i$ imovine, Newsletter Instituta za javne financije, No. 32

\footnotetext{
62 Urban, op. cit., note 39, p. 10

63 Bunn; Fornwalt, op.cit., note 2
} 
7. Krtalić, S.; Žgomba, B., Analysis of the tax wedge in the Republic of Croatia, The EU economic environment post-crisis: Policies, Institutions and Mechanisms, Juraj Dobrila University of Pula, Pula, 2016

8. OECD Publishing, Taxing Wages 2008-2009, OECD, Paris, 2010

9. OECD Publishing, Taxing Wages 2008-2009, OECD, Paris, 2010

10. OECD Revenue Statistics 1965-2010, OECD, Paris, 2011

11. Urban, I.: Jedna stopa unutar poreza na dohodak: utjecaj na raspodjelu poreznog tereta, Povremeno glasilo Instituta za javne financije, Newsletter No. 24, 2006

12. Urban, I., Porezno opteréénje rada u Hrvatskoj, Newsletter, povremeno glasilo Instituta za javne financije, No. 47, 2009

13. Zuber, M., Mogućnosti poboljšanja socioekonomskih i fiskalnih učinaka sustava obveznog mirovinskog osiguranja u Hrvatskoj, doktorska disertacija, Sveučilište u Rijeci, Ekonomski fakultet, rijeka, 2011

14. Tax Reforms in EU Member States 2015, Tax policy challenges for economic growth and fiscal sustainability X/2015, European Commission, Luxembourg: Office for Official Publications of the European Communities, ISBN 978-92-79-51181-3

\section{LIST OF NATIONAL REGULATIONS, ACTS AND COURT DECISIONS}

1. Law on personal income tax, Official Gazette, No. 109/1993

2. Law on personal income tax, Official Gazette, No. 95/1994

3. Law on personal income tax, Official Gazette, No. 106/1996

4. Law on personal income tax, Official Gazette, No. 127/2000, 150/2002

5. Law on personal income tax, Official Gazette, No. 177/04

6. Law on personal income tax, Official Gazette, No. 80/10

7. Law on personal income tax, Official Gazette, No. 115/2016, 106/2018

8. Law on financing regional and local self-government units, Official Gazette, No. 127/2017

9. Law on local taxes, Official Gazette, No. 115/2016, 101/2017

10. Law on contributions, Official Gazzette No. 106/2018

\section{WEBSITE REFERENCES}

1. Bejaković, P., Oporezivanje rada: Može li flat tax riješiti hrvatske probleme?, [https://prviplan. hr/analize-i-komentari/oporezivanje-rada-moze-li-flat-tax-rijesiti-hrvatske-probleme/] Accessed 15.02.2019

2. Blažić, H.; Trošelj, I., Mecunarodna usporedba poreznog opterećenja radne snage: Utjecaj nove metodologije na položaj Hrvatske, Financije i menadžment u globalnoj ekonomiji, Pula: Sveučilište Jurja Dobrile u Puli, Odjel za ekonomiju i turizam, 2012, p. 15, [https://bib.irb. hr/datoteka/589765.Blazic_Troselj_-_Copy.pdf] Accessed 15.02.2019

3. Bunn, D.; Fornwalt, A., A Comparison of the Tax Burden on Labor in the OECD, 2018, Tax Foundation, [https://taxfoundation.org/comparison-tax-burden-labor-oecd-2018/] Accessed 13.01.2019 
4. Deskar Škrbć, M; Drezgić, S.; Šimović, H., Tax policy and labour market in Croatia: effects of tax wedge on employment, Journal Economic Research-Ekonomska Istraživanja Vol. 31, 2018, [https://www.tandfonline.com/doi/full/10.1080/1331677X .2018.1456359?scroll=top\&needAccess=true] Accessed 05.05.2019

5. Eurostat statistics explained, [https://ec.europa.eu/eurostat/statistics-explained/index.php?title=Wages_and_labour_costs] Accessed 10.02.2019

6. Hodge, S. A.; Hickman, B., The Importance of the Tax Wedge on Labor in Evaluating Tax Systems, [https://files.taxfoundation.org/20180913095728/Global-Primer_tax_wedge.pdf] Accessed 15.02.2019

7. OECD Publishing, Taxing Wages 2018, [https://read.oecd-ilibrary.org/taxation/taxing-wages-2018_tax_wages-2018-en\#page7] Accessed 10.02.2019

8. Šimović, J. Socijalni učinci poreza na dodanu vrijednost, Revija za socijalnu politiku, Vol. 5, No. 2, 1998, [http://www.rsp.hr/ojs2/index.php/rsp/article/view/337/341] Accessed: 25.03.2019

9. Šimović, H.; Deskar Škrbić, M., Učinak promjena poreznih stopa na porezno opteréénje rada u Hrvatskoj, EFZG Working paper series, No. 15-13, 2015, [http://www.rsp.hr/ojs2/index. php/rsp/article/view/337/341] Accessed 15.02.2019

10. [http://www.consilium.europa.eu/en/press/press-releases/2016/09/09-eurogroup-statement/] Accessed 15.03.2019 